\title{
COMPARATIVE EFFICIENCY OF VARIOUS SUBSTRATES AND SUPPLEMENTS ON GROWTH BEHAVIOUR AND YIELD POTENTIAL OF Pleurotus flabellatus
}

\author{
K.K. GAUTAM ${ }^{1}$ \\ Department of Botany U.P. College, Varanasi, U.P., India
}

\begin{abstract}
An experiment was conducted to study the comparative efficiency of various substrates viz, wheat straw (Triticum aestivum l.), paddy straw (Oryza sativa l.), corn stalk (Zea mays l.) and typha leaves (Typha angustifolia) and different supplements such as wheat bran, rice bran, neem cake and fenugreek bran on growth behavior and yield potential of oyster mushroom (pleurotus flabellatus). In these investigations higher mushroom yield with biological efficiency (BE) of 86.6 percent was obtained from wheat straw followed by paddy straw (63 per cent biological efficiency). Wheat straw was further used as a substrate for different supplements observation. Wheat bran was recorded significantly superior supplement than other supplements and its biological efficiency was 95 per cent. The spawn running, premordia initiation and harvesting of first flush were also early in wheat bran supplemented substrate where it completed in the 13 days, 17 days and 21 days respectively.
\end{abstract}

KEYWORDS: Oyster Mushroom Substrates, Supplement, Yield and Pleurotus Flabellatus

The mushroom is good cash crop of India. Oyster mushroom (Pleurotus flabellatus) a delicious edible mushroom is gaining much important due to its short cropping period, lowest cost of cultivation and high potential. They can be grown on a wide variety of low value lignocellulosic wastes. The large quantity of which are generated annually from agricultural, forestry and food processing activities. The unexploited crops residues or plant wastes are increasing pressure on environmental pollution and create health hazards and surve as a constant source for survival of pest and pathogen of important crops. Even if one percent of agricultural wastes are used to produce mushroom, India will become a major mushroom producing country in the world (Tiwari and pandey, 2002). Mushroom cultivation therefore represents a prime example of the direct of low-grade residues into value added commodity. Present experiment was conducted at the Varanasi region to comparative efficiency of various locally available plant wastes and supplements for cultivation of Pleurotus flabellatus.

\section{MATERIALS AND METHODS}

The pure mushroom culture of Pleurotus flabellatus was obtained from N.R.C.M. solan (H.P.) and maintained on PDA which was used for preparing wheat grain spawn. The present study was carried out with different substrates viz. wheat straw (Triticum aestivum l.) paddy straw (Oryza sativa l.) corn stalk (Zee mays l.) And Typha leaves (Typha angustifolia) and different supplements wheat bran, rice bran, neem cake and fenugreek bran on growth behavior and yield potential of Pleurotus flabellatus which are easily available in Varanasi region of eastern Uttar Pradesh.

The dried and chopped wheat straw, paddy straw, maize stalk and Typha leaves we soaked in water for 14 hours and then drain off excess water. These soaked materials are pasteurized by autoclave at $65^{\circ} \mathrm{C}$ for 45 minutes. Well prepared wheat grain spawn (3 per cent moist weight basis) was mixed with moistened substrates and filled in polythene bags (15" X 10"). The mouth of each bag was tied with a rubber band and 8-12 holes made in each bag for proper aeration. The polythene bags were removed gently from the substrate after spawn running and these compact masses of substrate were kept in glass house under dark condition at seasonal temperature and humidity ranging between $25-30^{\circ} \mathrm{C}$ and $89-90$ per cent respectively during spawn running and formation of fruiting bodies.

Another experiment was conducted to comparative efficiency of different supplements such as wheat bran, rice bran, neem cake and fenugreek bran on same mushroom. The sun dried powered of above supplements were sterilized by autoclave at $15 \mathrm{lb}$ for 45 minutes each supplement@1.5 per cent dry weight basis was mixed with moistened substrates and pasteurized wheat straw before spawning. The experiment was conducted in a completely randomized block design (CRBD) with five replications for each treatment. Average value of observation with respect to period required for spawn running, premordia initiation, harvesting of first flush and total yield were recorded.

${ }^{1}$ Corresponding author 
Biological efficiency of mushroom on fresh weight basis was calculated as per the formula given by Chang and Miles (1989).

Biological
Efficiency (B.E.) $=\frac{\begin{array}{c}\text { Fresh weight of } \\ \text { Mushroom per Bag }\end{array}}{\text { Dry Weight of Substrate }}$
per Bag

\section{RESULTS AND DISCUSSION}

Results obtained from the present study are shown in Table 1. It is evident that utilized different substrates for growth behavior and yield potential of Pleurotus flabellatus. Wheat straw was produced significantly highest yield $428 \mathrm{gm} / \mathrm{bag}$ than the other substrates and was followed by paddy straw $315 \mathrm{gm} / \mathrm{bag}$. The days required for spawn run period, premordia initiation period and harvesting of first flush were also comparatively less in wheat straw substrate than required by other substrates.

Wheat straw has been found the best substrate for successful cultivation of oyster mushroom. This result was correlated to other workers, Bano et al., (1979), Savelgi et al., (1994), Hazarika (1998), Gautam and Ram (2007) under different condition.

Table 1: Comparative Efficiency of Various Substrates on Growth Behaviour and Yield of Pleurotus flabellatus

\begin{tabular}{|c|c|c|c|c|c|}
\hline Substrates & $\begin{array}{c}\text { SRP } \\
\text { (Days) }\end{array}$ & $\begin{array}{c}\text { PIP } \\
\text { (Days) }\end{array}$ & $\begin{array}{c}\text { FHP } \\
\text { (Days) }\end{array}$ & $\begin{array}{c}\text { Total Yield } \\
\text { (gms) }\end{array}$ & $\begin{array}{c}\text { SRP } \\
\text { Efficiency (\%) }\end{array}$ \\
\hline Wheat straw & 17 & 21 & 25 & 428 & 85.6 \\
Paddy straw & 18 & 23 & 27 & 315 & 63.0 \\
Corn stalk & 22 & 27 & 31 & 309 & 61.8 \\
Typha Leaves & 25 & 31 & 35 & 300 & 60.0 \\
C.D. (0.05\%) & & & & 3.85 & \\
\hline
\end{tabular}

Treatments are means of the five replications, SRP: Spawn Run Period, PIP: Premordia Initiation Period, FHP: First Harvesting Period

The result table-2 indicated that the organic supplements increased the yield significantly. Wheat bran was significantly (B.E. 95 per cent) superior comparatively to other supplements. Wheat bran was also significantly reduced spawn run period by 4 days and hastened the premordia initiation and harvesting of first flush than the control (without supplement). This result is in conformity with the finding of Hazarika (1998), Gautam and Ram
(2007). The wheat bran organic supplement has been reported to increase the yield of Pleurotus flabellatus. However wheat bran, a real waste supplement has been reported earlier by Marimuthu et al., (1994). The result of present investigation wheat straw and wheat bran found to be best substrate and supplement respectively for cultivation of oyster mushroom (Pleurotus flabellatus).

Table 2: Comparative Efficiency of Various Substrates on Growth Behaviour and Yield Potential of Pleurotus flabellatus

\begin{tabular}{|c|c|c|c|c|c|}
\hline Substrates & $\begin{array}{c}\text { SRP } \\
\text { (Days) }\end{array}$ & $\begin{array}{c}\text { PIP } \\
\text { (Days) }\end{array}$ & $\begin{array}{c}\text { FHP } \\
\text { (Days) }\end{array}$ & $\begin{array}{c}\text { Total Yield } \\
\text { (gms) }\end{array}$ & $\begin{array}{c}\text { SRP Biological } \\
\text { Efficiency (\%) }\end{array}$ \\
\hline Wheat bran & 13 & 17 & 20 & 475 & 95.0 \\
Rice bran & 15 & 19 & 22 & 401 & 80.2 \\
neem cake & 14 & 20 & 33 & 411 & 82.2 \\
Fenugreek bran & 15 & 20 & 23 & 345 & 69.0 \\
Control & $\mathbf{1 7}$ & $\mathbf{2 1}$ & $\mathbf{2 4}$ & $\mathbf{3 4 0}$ & $\mathbf{6 8 . 0}$ \\
C.D. $(0.05 \%)$ & & & & 6.49 & \\
\hline
\end{tabular}

Treatments are means of the five replications, SRP: Spawn Run Period, PIP: Premordia Initiation Period, FHP: First Harvesting Period. 


\section{ACKNOWLEDGEMENT}

We take this opportunity to acknowledge most humbly and with a deep sense of gratitude to the head department of Botany, U.P. College, Varanasi for providing Lab. facilities.

\section{REFERENCES}

Bano Z., Rajarathanam S. and Nagarajan N., 1979. Indian Mushroom Science, 10: 587-602.

Chang, S.T. and Miles P.G., 1989. Edible Mushroom and their cultivation. CRC Press, Boka Rattan, pp.256074.
Hazarika D.K., 1998. Mushroom Research, 7(1): 47-48.

Marimuthu T. Krishnamurti A.S. and Nalathambi P., 1994. Indian J. Mycology and Plant Pathology, 24: 103106.

Savalgi V. and Savalgi V.K., 1994. Indian J. Mycology and Plant Pathology, 24(3): 190-191.

Tiwari R.P. and Pandey M., 2002. Survey of Indian Agriculture, pp.165-167.

Gautam K.K. and Ram R.C., 2007. P. Microbial Diversity: Modern Trends, pp.295-307. 